January 2006

\title{
Multimodality and English education in Ugandan schools
}

\author{
Maureen Kendrick \\ University of British Columbia, Canada \\ Shelley Jones \\ Aga Khan University, shelley.jones@aku.edu \\ Harriet Mutonyi \\ University of British Columbia, Canada \\ Bonny Norton \\ University of British Columbia, Canada
}

Follow this and additional works at: http://ecommons.aku.edu/eastafrica_ied

Part of the Educational Methods Commons, English Language and Literature Commons, and the Instructional Media Design Commons

\section{Recommended Citation}

Kendrick, M., Jones, S., Mutonyi, H., Norton, B. (2006). Multimodality and English education in Ugandan schools. English Studies in Africa, 49(1), 95-114.

Available at: http://ecommons.aku.edu/eastafrica_ied/30 


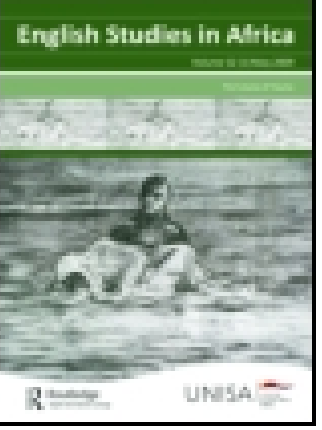

English Studies in Africa

\section{MULTIMODALITY AND ENGLISH EDUCATION IN UGANDAN SCHOOLS}

\section{Maureen Kendrick, Shelley Jones, Harriet Mutonyi \& Bonny Norton}

To cite this article: Maureen Kendrick, Shelley Jones, Harriet Mutonyi \& Bonny Norton (2006) MULTIMODALITY AND ENGLISH EDUCATION IN UGANDAN SCHOOLS, English Studies in Africa, 49:1, 95-114

To link to this article: http://dx.doi.org/10.1080/00138390608691345

册Published online: 30 Jan 2009.

Submit your article to this journal $\pi$

Џlll Article views: 201

Q View related articles ¿

Citing articles: 7 View citing articles 5 


\title{
MULTIMODALITY AND ENGLISH EDUCATION IN UGANDAN SCHOOLS
}

\author{
Maureen Kendrick \\ University of British Columbia, Vancouver \\ Shelley Jones \\ University of British Columbia, Vancouver \\ Harriet Mutonyi \\ University of British Columbia, Vancouver \\ Bonny Norton \\ University of British Columbia, Vancouver \\ University of the Witwatersrand, Johannesburg
}

\begin{abstract}
T $n$ all societies children have many layers of representational resources available to them. Play, movement, song, drama, language and artistic activity are but some of the modalities by which they learn to make sense of their world (Short, Kauffman and Kahn 160). The concept of multimodal ways of communicating, however, although very much in vogue in literacy studies, is not a new model within the Ugandan communities in which we work. In many parts of Uganda, indigenous knowledge and ways of communicating have been integrated into non-formal learning contexts, particularly in Freirean-based adult literacy programmes such as UPLIFTUganda (Pokorny 10-11) and REFLECT (Attwood, Castle and Smythe 137158). Within the formal school system, however, teachers are often constrained in their ability to recognize alternative or indigenous modes of representing and communicating knowledge due to a strong emphasis on examinations, teaching to the curriculum and a lack of resources and teacher training, particularly in rural areas. This is a particular problem in the higher
\end{abstract}


classes (Primary 5 and up). The need for pedagogical and curricular change has become even more pressing with the cultural, economic, social and political changes that are inherent in the new century. Ugandan schools, like their counterparts in other parts of the world, must now grapple with the question, 'What will it mean to be a reader and writer in the 21 st century?' (Luke and Elkins 5).

In Uganda, the vision of literacy in the future is linked inextricably to the English language. Given that English is a third, even fourth, language for the majority of students, there is a pressing need for including in school curricula alternative modes of representation and communication that acknowledge the limits of language (Kress and Jewitt 1-18; New London Group 60-92; Stein 95-115). Mushengyezi argues that in many parts of Africa governments and their development partners are often guilty of transplanting communication models from the developed world into local African communities (107). A theory of multimodality is undergirded by the assumption that within a particular social, cultural and linguistic context, people make meaning through multiple means. These indigenous modes of communication are deeply embedded in the local culture rather than being transplants.

In the spirit of this debate, this article draws on our current research in Uganda to address the following two questions:

1. To what extent can the modalities of drawing, photography and dramatic performance enhance teachers' understanding of the way students use the English language?

2. How can students' use of the English language inform English teaching and curriculum development?

We begin by locating the study within the broader literature, then turn to an examination of the centrality of English in Ugandan schooling before introducing our research sites. Our research on the use of multimodality in six schools, two in southwestern Uganda and four in eastern Uganda, is presented with a focus on drawing, photography and drama, which are of central interest in these research sites. We conclude with the recommendation that multimodal pedagogies be incorporated more fully into the Ugandan English curriculum, while also highlighting the challenges teachers face in this regard.

The importance of multimodality in pedagogical sites is receiving greater attention amongst scholars in different regions of the world. Until recently there has been a privileging of written modes of representation in theories of 
communication. However, scholars are increasingly recognizing that in any communicative mode, language, whether written or spoken, is only part of the meaning-making process (Kress and Jewitt 1-18). Indeed, any communicative event involves simultaneous modes whereby meaning is communicated in different ways through images, gestures and speech. Kress asserts that we need to take a completely fresh look at theories of communication in order to set a new agenda that includes the full range of semiotic modes in use in a particular society (182-202). Integral to this new agenda is how cultures select from, and choose to develop, particular multimodal possibilities for communication (Kress and van Leeuwen 1-14)

The key notion in any semiotic mode is the 'sign', which is comprised of forms (signifiers) such as colour, perspective, line and movement that are used to realize meanings (signifieds) (Kress and Van Leeuwen 5-12). Signmakers, within a particular sociocultural context, use the forms they consider most apt for the expression of their meaning, in whatever medium they have 'to hand' (for instance the use of a cardboard box to make a house or the use of music to portray mood). The interests of the sign-maker, at the moment of making the sign, lead her or him to choose an aspect or feature of the object being represented as critical for representation. The resources used for representing the object have histories; they are 'at once the products of cultural histories and the cognitive resources we use to create meaning in the production and interpretation of visual and other messages' (Jewitt and Oyama 136).

The human body has a wide range of communicative possibilities; each of the senses is attuned in a specific way to the natural environment, providing us with highly differential information (Kress 184). A multimodal approach to learning begins from a theoretical position that treats all of these modes of meaning-making as equally significant. Many of these modes, however, particularly visual, musical and performative, have been removed from school curricula in Western contexts except as specialist activities (Kress 183). As Sidelnick and Svoboda argue, 'aesthetic, narrative, and reflective inquiries using the arts help children attain new conceptual language to organize and express their learning, and serve as instruments for acquiring knowledge' (174). Ideally, approaches to teaching and assessment should focus on the individual child's strengths and styles of representation. There are a growing number of language arts educators and researchers (Davis and Reed 101118; Shohamy 72-92) calling for a multimodal perspective that recognizes art, music, dance, drama and film as forms of literacy that play an important role in the development of children's lives. This broader definition of literacy 
goes beyond language symbols to that of multiple symbols. Critical to this perspective is the understanding that symbol systems other than language are not 'tack-ons', but rather relevant options for creating and expressing meaning.

In order to address the potential impact of multimodal pedagogies for English education in Uganda, it is important to provide an overview of current uses of English in Ugandan schools. For all Ugandan students, English is the language of instruction in all subjects from Primary 4 onwards. Although some Ugandan children grow up speaking English in the home, this is rare, and generally a characteristic of affluent families in urban centres. Only approximately $5 \%$ of the population in Uganda has access to contemporary forms of communication in English such as television, radio, and the internet (Mushengyezi 107). Instead, the predominantly rural population relies on indigenous media to communicate with one another.

The teaching of English in Uganda has not been without controversy, and the question of whether English in its standard form or Englishes, as in world Englishes, should be the focus of teaching has yet to be resolved (Fisher 34 40). In 1998, there were 27 teacher resource centres responsible for inservice education for teachers and the distribution of English, Maths, and Science textbooks and teaching materials. In addition, starting in 1996, lead teams developed and implemented in 39 districts modules targeting teachers' expressed needs. Yet, according to Fisher, spoken and written English are a struggle for most students, including students at the university level (36).

The research report here is part of a larger study being conducted in three districts of Uganda: Masaka in the southwest, Mbale in the east and Nebbi in the northwest. The broader study, which began in August 2003, is centrally concerned with the relationship between literacy, gender and sustainable development, and includes both formal and informal schooling, children and adults. For the purposes of this article, we focus on six selected schools: two rural schools in Masakam (Banda Primary School and Banda Secondary School), one urban school (Mount Elgon Secondary School) and three rural secondary schools (Bulula Girls' School, Masulila High School and Namisidwa High School) in Mbale. All schools except Bulula Girls' School have a mixed population of girls and boys. Data collection involved interviews with students and teachers in all six schools, document analysis of collected student drawings and photographs in Banda Primary and Banda Secondary, respectively, as well as observations of student dramatic performances in Mount Elgon Secondary. We also interviewed curriculum planners at the Ugandan Ministry of Education's Curriculum Centre in Kampala and studied the guidelines for the English curriculum. Data collection took place between September 2004 and April 2005. Further details of the specific methodologies 
used will be discussed with reference to each research site. Pseudonyms for students and schools are used throughout this article.

\section{DRAWINGS AS A WINDOW ON PRIMARY SCHOOL STUDENTS' PERCEPTIONS OF ENGLISH LITERACY}

Studies of children's visual representations of the reading and writing practices in their lives, both inside and outside school (Kendrick and McKay 109-28; Kendrick, McKay, and Moffatt 185-204) show that children not only have very rich images of literacy, but also that their drawings reveal complex understandings about the multi-faceted and interactive nature of literacy, including how the students perceive themselves and others in relation to literacy. In this vignette we focus broadly on a collection of drawings from sixty Primary 6 students in Banda Primary School, with a specific focus on three of the drawings. The students all had two years of curriculum instruction in English.

The procedure we followed in soliciting the drawings included group discussions and interviews. The students, who were all in the same class, met with a research assistant to discuss and draw pictures of their ideas about literacy in their lives in school, outside school, and in the future. At the time, the research assistant was volunteering in the school as their English teacher. Because our goal was to explore the students' images and ideas as evident in their drawings, we used open-ended questions to guide the discussions rather than a rigid format. We asked for instance, what kind of reading/writing do you do in school/outside of school? How do you think you will use reading/ writing in the future? The directions for the drawing task did not specify who or what should be in the drawing or where it might be located. Students were simply asked to draw a picture of reading and/or writing. The discussion provided the impetus for drawing and we were aware that hearing the ideas of their peers could influence what the children might draw.

We used a modified version of Dyer's checklist for exploring what the drawings as signs might symbolize within this particular socio-cultural context. Specifically, the drawings were coded and analyzed according to the following: representations of bodies (age, gender, race, hair, body, size and looks), representations of manner (expression, eye contact and pose), representations of activity (touch, body movement and positional communication), and props and setting. We begin with a brief description of the visual, then move beyond this basic level to try to perceive links and relationships to other elements and layers of the drawing (Dyer 93-106). In the first vignette, we concentrate on three drawings to illustrate the range of ways in which the students 


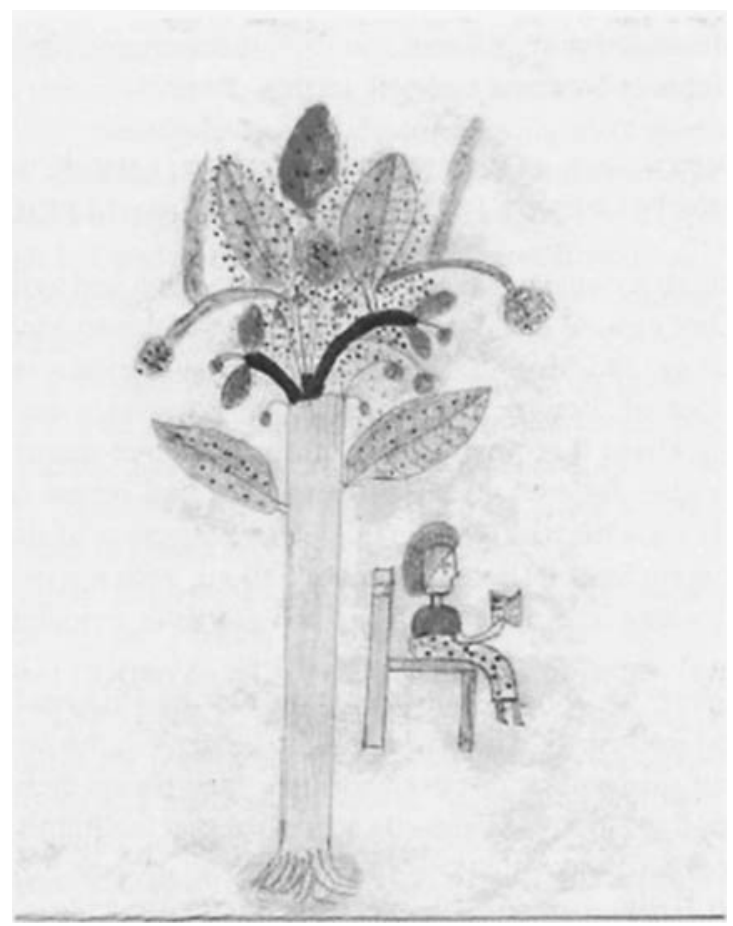

Figure 1.

portrayed their understanding of the use and meaning of English reading and writing in their community. These drawings reflect the most typical meanings and uses of literacy portrayed by this group of Primary 6 students.

Nakate, like several other students, drew a picture of herself reading, sitting in a chair under a tree. The chair is symbolic of serious study rather than reading for pleasure or leisure. Nakate is reading Young Talk, a monthly student newspaper focusing on HIV/AIDS awareness and other issues that are of interest to pre-teens (see Figure 1). She explained that reading Young Talk helps her to learn words and their spelling (in English). Reading Young Talk requires a high level of English language ability, and Nakate's decision to include this newspaper in her drawing positions her as someone who has or wants to have - a high level of English literacy skills. Her manner of dress in the drawing provides some evidence that she may be imagining this proficient literate identity in the future, possibly when she is in secondary school. Her hair is long and more typical of secondary school girls than 
primary school girls, who keep their hair cropped close to their head. She is wearing high heels and a fancy dress, which is generally the attire of secondary school girls when they are travelling somewhere away from home or school.

Nassozi's drawing includes two scenes; in one she is standing under a tree reading English books, in the other she is sitting in a chair reading Young Talk (see Figure 2). In the first scene her facial expression and direct gaze at the viewer project self-confidence in her identity as a reader of English texts. The second scene, where she is reading in a chair, denotes being a serious student. In this rural area, where English is a third or fourth language for many students, this young girl clearly understands the global power of English and, in particular, that learning about the outside world is largely dependent on English language proficiency. As she explained in writing, 'English is the best language', and reading English books is important 'because I want to [know] the world'. In both scenes, Nassozi portrays herself as an older student rather than a Primary 6 student. Her hair is longer and quite fashionable; her

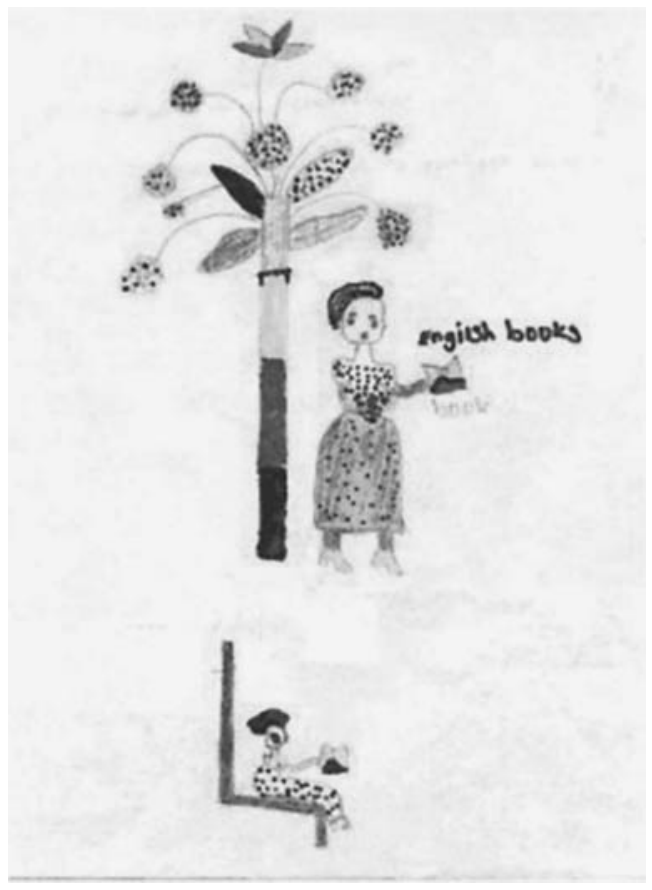

Figure 2. 
style of dress, high heels and a smart dress, is typical for a young woman travelling away from home or school. Similar to Nakate's depiction of self, Nassozi also appears to be imagining this literate identity in the future when she is a secondary school student.

Nsubuga drew himself and his friend under a tree reading Science books (in English), which he referred to as 'test books' (see Figure 3). He explained that he is studying test books to 'know the environment'. Passing tests at this level is dependent on students' knowledge of English across a range of disciplines, including Science. Both boys are sitting on the ground under a tree. Their positioning is relaxed and the expression on their faces is open and jovial, giving the impression that they are enjoying what they are doing. Their manner of dress, which is casual, and the inclusion of the house, indicates that the boys are at home. The football, which is positioned to the

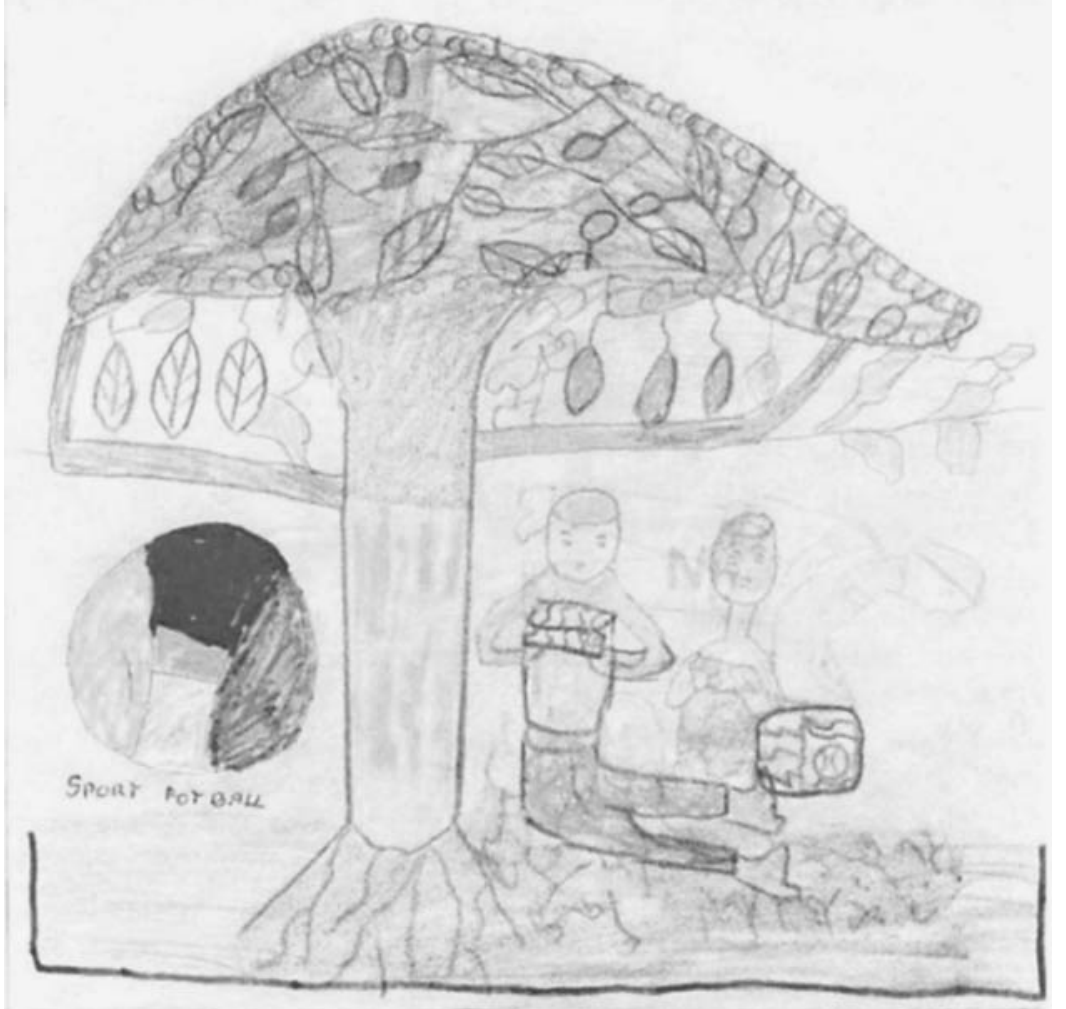

Figure 3. 
left of the reading scene and is equal in stature, adds an interesting dimension to the drawing and may in part explain the jovial expression on the boys' faces. The football has been placed in direct competition with the reading event. It is as though the boys are simultaneously communicating what they think is expected of them in relation to school (that is, to be a serious student) alongside what captures their attention in reality.

In all of the drawings, the students situate themselves as the central literacy participants around which the literacy event or practice depicted revolves. In this rural area, few adults read and write in English and the identity of reader or writer holds considerable status. The inclusion of props such as Young Talk, English books and Science texts are symbolic of the status associated with membership in the English literate world. The vast majority of the drawings depicted settings other than school, and particularly outdoor settings, which is reflective of the multiple contexts in which reading and writing take place in this community. Students also included participants other than themselves, most typically, friends and siblings. Strikingly absent from all of the drawings were teachers, parents and other adults as mediators of literacy. From a pedagogical perspective, peers and siblings may play a more important role in scaffolding English literacy learning than teachers and parents or guardians. Gregory (2001) describes this interaction as a synergy, a 'unique reciprocity whereby siblings [and peers] act as adjuvants in each other's learning' (309). The students portray themselves as actively engaged in the reading process. Facial expressions convey focus and interest in what they are reading, as they sit in chairs under trees or relax on the ground. Many of the girls also depict themselves seated in a traditional pose on the ground, with their legs to one side and modestly covered by their dress.

Writing as a literacy practice was virtually non-existent other than in the writing of examinations. In Uganda, where social interaction has historically been the predominant means of communication, writing, which is often considered a very private and individualistic activity, may not be viewed as an integral part of everyday social activities.

\section{LEARNING THROUGH PHOTOGRAPHY IN A SECONDARY ENGLISH CLASS}

The next vignette features the work of nineteen secondary school girls in Senior 3 (ages 16 to 19). The purpose of this study was threefold: to provide the girls with a visual, artistic way in which to explore and view their lives through both the lens of the camera and photographic images; to provide the girls with an opportunity to become familiar with 'technology' they had not 
used before, and to learn to read/use English manuals to understand cameras; also, to provide a way of developing communicative English capacity by using photographs as an entry point for discussion, writing and critique. Photography is a powerful ethnographic research tool. Hamilton proposes that photography be used in creative ways to stimulate reflection on theory, as a tool for gathering evidence, as a means to create visual representations of various aspects of culture, and as a source of data generation (19). Prosser emphasizes the use of photographs in creating cultural inventories, photographic records of contexts/situations, as well as the production of conceptual images and data collection (397-411).

None of the girls' families possessed a camera, and most of the girls had never held a camera before, let alone taken a picture. If their families had photographs, they tended to feature prominently in the girls' homes, either on the walls, or carefully placed in photo albums displayed on a table. The photographs were generally formal, posed images of family members featuring, for example, the wedding of parents, one of the family members at a special occasion, or sometimes family photos. These pictures were almost always taken by professional photographers, individuals who own their own cameras and are paid a small amount for their picture-taking services.

The girls were divided into pairs, and each pair was given a camera to handle and examine. Each camera part and its functions was introduced. The pairs of girls were given manuals for their cameras, and the group as a whole read through the manual, step by step. Students were then asked to draw and describe each camera part to present to the others. Finally, the girls were taught to load film and batteries, turn the cameras on and off, and use the flash and zoom. The photography assignment involved the following three steps:

1) Brainstorm and write down five things that represent who you are (objects, activities, people, etc). Take one picture of each of five different things that 'represent' who you are;

2) Brainstorm and write down five of your favourite places, then take one picture of each of these places;

3) Brainstorm and write down the kinds of work that girls and women do. In groups of three, take pictures of five of these activities (see Figures 4 and 5 for examples of the girls' photos).

The film was processed into strips of negatives, and the girls chose images that would reproduce into good pictures. Details of the subject of the pictures 


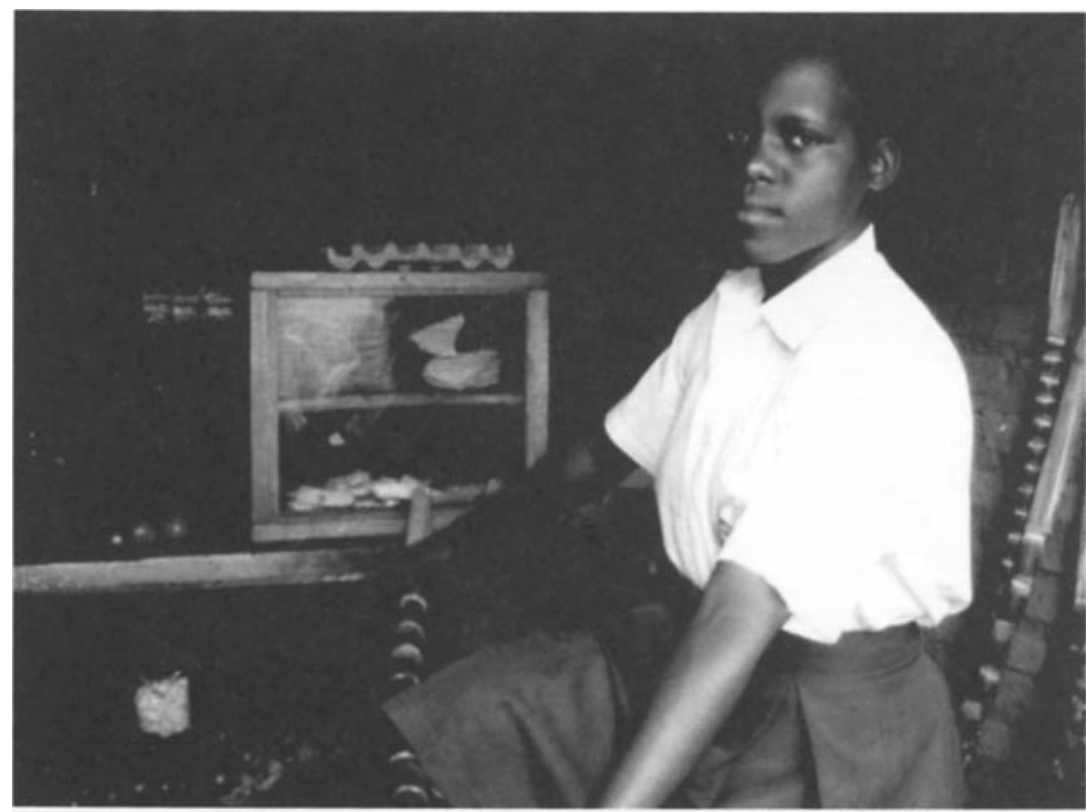

Figure 4.

were used as focal points for description, both orally and in writing. The photographs were also used to explore new ways of seeing things.

In journal writing and interviews, the girls discussed what they learned through their participation in the research project. Some focused on what they learned in terms of the artistic element of photography, such as composition, framing and lighting; some focused on the pragmatic aspects of knowing how to use a camera (for instance, to earn money as a 'paid photographer'); and others considered how learning to use a camera made them feel more confident about learning about other types of 'technology.' Of particular note, however, was that almost all of the girls also mentioned increased English ability as something that they had gained and were happy about. The following is representative of many of the comments made by the girls:

In this group you gives [us] the camera and we take it in our villages and photo our favourite things ... which is very wonderful thing ... we have improved our English and learnt very interesting things. 


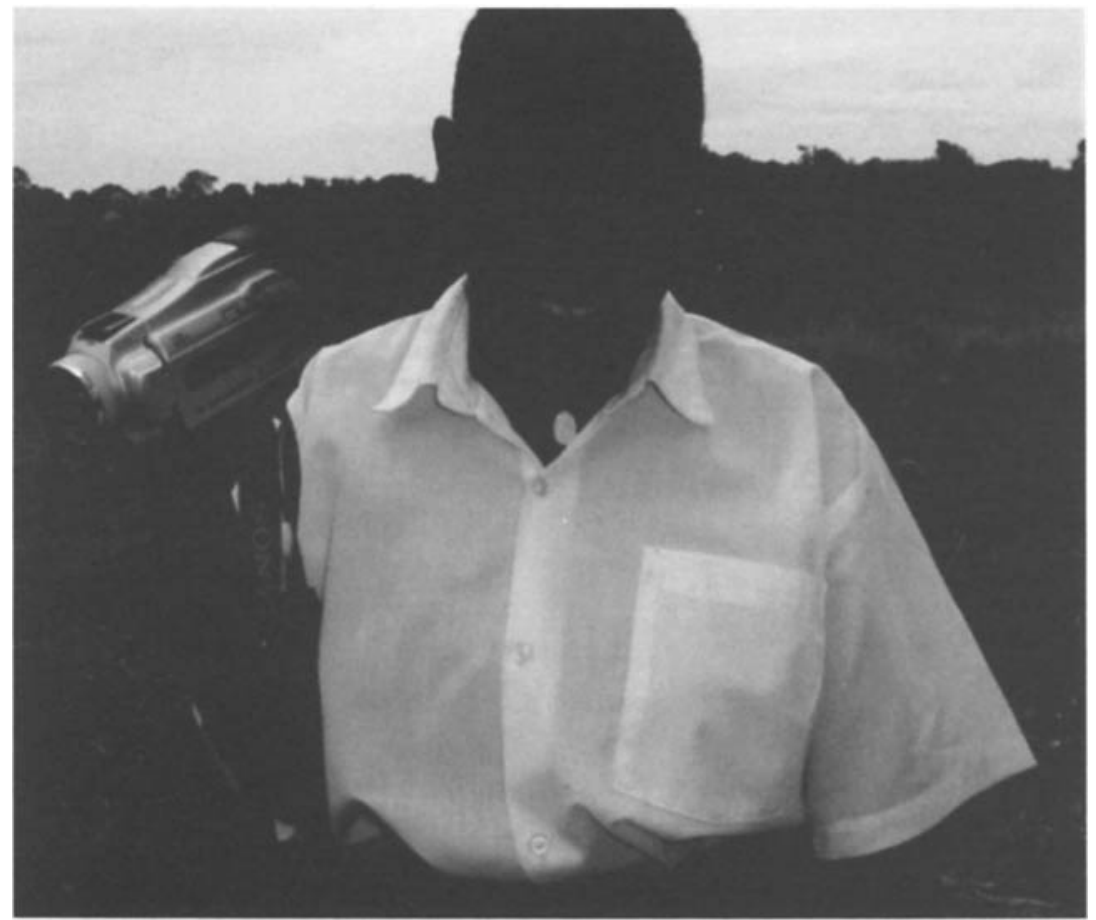

Figure 5.

When asked directly how (if at all) they believed that this research project facilitated learning English, the girls mentioned reading comprehension (as a result of studying the manuals), writing (writing about their pictures and in their research journals) and listening and speaking (from group discussions, meetings and presentations). In addition, they said that their participation in this research project also served to improve their 'school' English.

\section{USING DRAMA TO COMMUNICATE HIVIAIDS AWARENESS TO STUDENTS IN MBALE DISTRICT}

Mushengyezi (2003) makes a case for rethinking indigenous media as forms of public communication in Uganda, arguing that the rituals of 'talking' drums and orality are highly effective in disseminating information on health in Uganda (110-115). He suggests further that indigenous forms of communication are embedded in the cultural ideology of the people and that, as Uganda adopts modern ways of communication, communication planners 
should take into account how these cultural forms of information can enhance learning. The work of other scholars, such as Bolton (39-47), Clyde (150160) and Schofield and Rogers (238-248), also supports the use of dramatic performance for the purposes of learning.

One of the goals of our research in the Mbale District was to better understand how drama is used to educate secondary school students about HIV/AIDS, and to determine what benefits drama might have for English education. In the four schools we visited, we found that HIV/AIDS clubs were active organizations in the schools, and that these clubs made regular use of drama to communicate AIDS information, in English, to the student body. Most of the drama shows included mimes, poetry, songs, skits and role-plays interspersed with short messages. These different aspects of dramatic performance involved writing as the student members of the HIV/AIDS clubs edited, practised and polished the scripts for the purposes of presentation. Further, a student leader noted that all performances convey messages in a 'simplified language which in most cases contain the students' private dialect'. This is in an attempt to capture students' interest as they watch the drama and also gives the audience a sense of identity as the language used is mainly a 'modified' English that students can easily relate to. Furthermore, ideas that would otherwise be abstract are simplified through the language the drama group uses. As a result, the students spend less time trying to make sense of what is being dramatized, and more time enjoying the drama.

Why use drama in the school environment? The club chairperson in one school noted as follows:

You see, students will usually not turn up in big numbers when you are giving a talk on HIV/AIDS. So we thought that maybe if we organize the drama as a sort of entertainment for the school, we could have many students attending and we can use the opportunity to talk about HIV/AIDS. The drama is always about HIV/AIDS, but it is also fun so students come to watch and listen. Drama is very good way of communicating HIV/AIDS to the students.

This view was supported by the chairperson of another club, who noted that:

Students think they have heard enough about HIV/AIDS, so they don't want to pay attention when there is a general talk on AIDS. And yet there is a lot they don't know. We use drama, which is believed to be a form of entertainment, to convey the messages on HIV/AIDS. 
There are many ways in which students decide on the format of the performances. According to one of the patrons, the club decides on a theme and develops a dramatic performance around the theme. In most cases, the theme is one that is directly linked to the students' environment. After the theme has been chosen, members of the club decide on the role they will play and practice starts. A student leader adds, 'it can take us like a month just to practise before we make a public presentation'. To the students in the clubs, it is an exciting but tiring time as well because most of the practice is done after school hours. Apart from designing their own drama, the schools also receive suggestions from the Ministry of Education on what the central theme of the National AIDS Day will be.

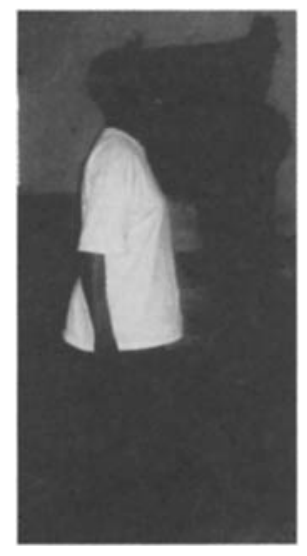

Figure 6. The patron of one school noted that, 'the students who offer literature are encouraged to write out the play and then the members of the club act it out.' In another school, the co-patron, who is a literature teacher, develops the play and then the students are assigned roles. It can be inferred that the literary skills developed by the students in the AIDS clubs extend to prescribed literacy texts used in other subjects such as English and Literature. One poem, written and performed by the Head of the HIV/AIDS club in one of the Mbale schools, provides an illustration of the kind of material produced by the students. It was received with much enthusiasm by students participating in an HIV/AIDS club student exchange in October 2004. Indeed, the audience participated actively in the presentation by serving as a chorus whenever the words 'two choices' and 'that's fine' were uttered. An excerpt from the poem is provided below. The young performer is pictured in Figure 6.

\section{CHOICES FOR YOUNG PEOPLE}

When preparing for a dance there are two choices

You either dance with a partner or you dance alone

If you dance alone that's fine.

But if you dance with a partner, my friend, there are two choices You either have sex with her or you don't have sex with her If you don't have sex with her, that's fine.

But if you have sex with her, my friend, there are two choices You either have protected sex or unprotected sex.

If you have protected sex, that's fine. 
But if you have unprotected sex, my friend, there are two choices.

You either get the virus or you don't get the virus

If you don't get the virus, that's fine

But if you get the virus, my friend, there is one choice,

That is death.

Even though English is a second or additional language for students in Uganda, it is critical that they gain a certain level of proficiency in English for educational and career advancement. Nevertheless, English is generally used only during class time, and is seldom spoken in the home or local community, particularly in rural areas. This poses many problems for students who struggle to express themselves effectively in English - both in writing and orally. The case studies described above provide much insight into ways in which multimodal pedagogies, in particular drawing, photography, and drama, can broaden teachers' understanding of the way students use the English language, and how their use of English can be enhanced. When students engage in projects in which they are encouraged to explore their own familiar worlds with English as the language of communication - they significantly develop their spoken, written, reading and aural English language skills. In the projects described, English, in tandem with drawing, photography and drama, is used to convey thoughts, ideas and information generated from lived experiences. At the core of each of these projects is student ownership of meaning-making.

Research consistently shows that drawing as a means of investigating what children know has the potential to advance our knowledge of the role visual memory plays in human understandings of the world (Peterson 7). Research on drawings can well be extended to other visual media, including photography and drama. The data from our study suggest that visual media have unrealised potential for understanding how children use alternative symbol systems to make sense of the literacies and experiences in their lives. The drawings, photographs and dramatic performances are comprised of familiar images and symbols from the students' environment, and provide insight into both literacy practices and everyday experiences.

For the primary school students, English literacy is about reading. In fact, writing for any purpose was virtually absent from their drawings. Overwhelmingly, the students made reference to pragmatic reasons for being able to read in English - to get a job, learn skills to assist their families and communities (for instance, sanitation), and pass examinations. Reading for leisure or pleasure purposes was not portrayed in any of the drawings, perhaps because domestic duties and preparation for exams occupies much of the 
students' time outside of school. For the secondary school students, the use of multimodal pedagogies encouraged students to engage with diverse aspects of the English language, including reading, writing, listening, speaking, drawing and singing. In the drama workshops, the method of allowing students to develop their own subtexts has been shown to improve writing skills (Bitz 574-586), creativity (Stein 95-115), and understanding of the phenomenon under study (Bolton 39-47; Clyde 150-160). In the photography project, the students' perception of English as being a somewhat restrictive and artificial medium of instruction began to diminish as English began to be used for communication, expression and ownership of meaning. One of the girls (Rose) expressed this point clearly in an interview:

Shelley: How is learning English through doing a project like this different from learning English in the classroom?

Rose: In class teachers write on the blackboard and we just listen.

Shelley: In the research project how do you use English?

Rose: Communication.

Shelley: Do you learn more by studying English or by communicating in English?

Rose: Communicating.

Shelley: Why?

Rose: Because when you communicate, you think your own English.

In this article, we have made the case that multimodal pedagogies that include drawing, photography and drama have significant potential for enhancing teachers' understanding of the way English is incorporated into students' lives and how students can improve their understanding and use of the English language. In many ways, multimodal pedagogies represent a hybridization of indigenous and contemporary forms of communication. Drawings, as Vygotsky (112-113) notes, are children's earliest representations of experience and stimulate their narrative impulse to create stories. By complementing such drawings with written narratives, teachers might encourage younger children to experiment not only with diverse reader identities, but also a range of writer identities. With reference to photography, it is clear that the careful and rigorous process of taking pictures of meaningful places, people and events gives children a sense of ownership over their worlds. As Norton (145-146) notes, ownership of meaning-making is crucial 
for the development of literacy. What makes the use of photography particularly effective is the contextual use of reading, writing, listening and speaking activities. Finally, we have argued that drama provides the opportunity for students to experiment with different forms of English, and that the writing of plays and poems used for dramatic performance complement the oral and visual dimensions of performance.

In sum, we would like to emphasize that although the modes of drawing, photography and drama are by no means new pedagogies, incorporating them more systematically into school curricula offers innovative possibilities for how teachers might validate students' literacies, experiences and cultures, to support English language learning in the classroom. As Mushengyezi (107117) reminds us, communication planners in Uganda should not overlook the importance of indigenous forms of communication, such as popular theatre, drumming, and storytelling for enhancing student learning at all levels. Our research suggests that drawing, photography and drama offer exciting insights for teaching and curriculum development primarily because they invite opportunities for students to perceive and situate themselves in new ways within their societies and communities.

Although we want to emphasize the rich potential for student learning and curriculum development that multimodal pedagogies afford, we simultaneously want to acknowledge the inherent challenges of translating these possibilities into Ugandan classrooms. Many Ugandan teachers are spontaneously using multimodal pedagogies in their classrooms (for instance, through song and performance) and are constantly seeking new ways to help students understand complex concepts. But even as the Ugandan government is advocating new approaches to teaching and is considering revamping the teacher education programme, professional development for teachers is not widely supported. Typically, teachers must pay for their own professional development activities, which they are expected to schedule during their holiday time. Supporting professional development activities around multimodal pedagogies would facilitate a more in-depth understanding of how and why to include alternative modes of representation and communication to enhance student learning and target curricular goals. Providing opportunities for teachers to work together to develop new pedagogical approaches to teaching in general, and the teaching of English in particular, may represent an important first step toward the government's current goal of producing students who create jobs rather than seek them. 


\section{ACKNOWLEDGEMENTS}

We wish to acknowledge the generous support of the Social Science and Humanities Research Council of Canada, University of British Columbia Hampton Research Fund and the International Development Research Council (now CoreNet Global).

\section{WORKS CITED}

Attwood, Gillian, Jane Castle and Suzanne Smythe. 'Women are Lions in Dresses: Negotiating Gender Relations in REFLECT Learning Circles in Lesotho'. Women, Literacy, and Development. Ed. Anna Robinson-Pant. London: Routledge, 2005: 137-158.

Bitz, Michael. 'The Comic Book Project: Forging Alternative Pathways to Literacy'. Journal of Adolescent \& Adult Literacy 47 (2004): $574-586$.

Bolton, Gavin. 'Drama in Education and TIE: A comparison'. Learning Though Theatre: New Perspectives on Theatre in Education. Ed. Anthony Jackson. London: Routledge, 1993: 39-47.

Clyde, Jean. 'Stepping Inside the Story World: The Subtext Strategy - A Tool for Connecting and Comprehending'. The Reading Teacher 57 (2003): 150-160.

Davis, Harriet and Yvonne Reed. 'Assessing Multimodal Texts in Multilingual Classrooms'. Perspectives in Education 21.1 (2003): 101-118.

Dyer, Gillian. Advertising as Communication. London: Routledge, 1982.

Fisher, Pamela. 'English in Uganda: Of Standard and Standards'. Language and Literacy in Uganda. Ed. Kate Parry. Kampala: Fountain Publishers, 2000: 34-42.

Gregory, Eve. 'Sisters and Brothers as Language and Literacy Teachers: Synergy Between Siblings Playing and Working Together'. Journal of Early Childhood Literacy 1 (2001): 301-322.

Hamilton, Mary. 'Expanding the New Literacy Studies: Using Photographs to Explore Literacy as Social Practice'. Situated Literacies: Reading and Writing in Context. Ed. David Barton, Mary Hamilton and Roz Ivanic. London: Routledge, 2000: 16-34.

Jewitt, Carey and Oyama, Rumiko. 'Visual Meaning: A Social Semiotic Approach'. Handbook of Visual Analysis. Ed. Theo van Leeuwen and Carey Jewitt. London: Sage, 2001: 134-156. 
Kendrick, Maureen and Roberta McKay . 'Drawings as an Alternative Way of Understanding Young Children's Constructions of Literacy' Journal of Early Childhood Literacy 4 (2004): 109-128.

Kendrick, Maureen, Roberta McKay and Lyndsay Moffatt. 'The Performance of Self in Children's Drawings of Home, School and Community Literacies'. Portraits of Literacy across Families, Communities, and Schools: Intersections and Tensions. Ed. Jim Anderson, Maureen Kendrick, Theresa Rogers and Suzanne Smythe. New Jersey: Lawrence Erlbaum, 2005: 185-204.

Kress, Gunther. 'Multimodality'. Multiliteracies: Literacy Learning and the Design of Social Futures. Ed. Bill Cope and Mary Kalantzis. London: Routledge, 2000: 182-202.

Kress, Gunther, and Carey Jewitt. 'Introduction'. Multimodal Literacy. Ed. Carey Jewitt and Gunther Kress. New York: Peter Lang, 2003: 118.

Kress, Gunther and Theo Van Leeuwen. Reading Images: The Grammar of Visual Design. London: Routledge, 1996.

Luke, Allan, and John Elkins . 'Reinventing Literacy in "New Times", . Journal of Adolescent \& Adult Literacy 42 (1998): 4-8.

Mushengyezi, Aaron. 'Rethinking Indigenous Media: Rituals, 'Talking' Drums and Orality as Forms of Public Communication in Uganda'. Journal of African Cultural Studies 16 (2003): 107-128.

New London Group. 'A Pedagogy of Multiliteracies: Designing Social Futures'. Harvard Educational Review 66 (Spring 1996): 6092.

Norton, Bonny. 'The Motivating Power of Comic Books: Insights from Archie Comic Readers'. The Reading Teacher 57 (2003): 140-147.

Peterson, Rita. 'Visual Memory and Language: A Study of Children's Use of Art and Language to Communicate their Knowledge of Science'. Paper presented at the annual meeting of the National Association for Research in Science Teaching. Oak Brooks, IL, 1997.

Pokorny, Bradley. 'In Uganda, A Focus on Practical Knowledge Boosts Literacy Efforts'. One Country 16 (2004): 10-11.

Prosser, Jon. 'Personal Reflections on the Use of Photography in an Ethnographic Case Study'. British Educational Research Journal 18 (1992): 397-411.

Rose, Gillian. Visual Methodologies. London: Sage, 2001.

Schofield, Andrew and Theresa Rogers . 'At Play in Fields of Ideas'. Journal of Adolescent \& Adult Literacy 48 (2004): 238-248. 
Shohamy, Elana. 'Assessment in Multicultural Societies: Applying Democratic Principles and Practices to Language Testing'. Critical Pedagogies and Language Learning. Ed. Bonny Norton and Kelleen Toohey. Cambridge: Cambridge University Press, 2004: 72-92.

Short, Kathy, Gloria Kauffman and Leslie Kahn. 'I Just Need to Draw': Responding to Literature across Multiple Sign Systems'. The Reading Teacher 54 (2000): 160-171.

Sidelnick, Mark and Marti Svoboda. 'The Bridge between Drawing and Writing: Hannah's Story'. The Reading Teacher 54 (2000): 174 184.

Stein, Pippa. 'Representation, Rights and Resources: Multimodal Pedagogies in the Language and Literacy Classroom'. Critical Pedagogies and Language Learning. Ed. Bonny Norton and Kelleen Toohey. Cambridge: Cambridge University Press, 2004: 95-115

Vygotsky, Lev. Mind in Society: The Development of Higher Psychological Processes. Cambridge, MA: Harvard University Press, 1978. 